\title{
INTRODUCTION
}

\section{Climate change: Positioning Ireland, positioning geography}

\author{
John Sweeney* \\ Department of Geography, National University of Ireland Maynooth, Ireland
}

\begin{abstract}
The exposed location of Ireland has always rendered it vulnerable to weather and climate extremes. Awareness that future climate change will pose a complex mix of impacts necessitates strategic thinking on how best adaptation to future conditions can be achieved for Ireland. This extended introduction to seven papers examines how different perspectives and tools can be brought to bear on the problem. First, a historical context is needed to learn from past mistakes and inform future strategy. Current uncertainties are then addressed with reference to hydrological modelling where the need to act in advance of scientific certainty is emphasised. Analytical techniques involving satellite remote sensing and climate envelope modelling are then shown to have considerable utility for managing valuable habitats and biodiversity change. Weaknesses in governance systems are highlighted with reference to the Cork floods of November 2009, and at a local government level, where an urgent need for leadership at a central government level to drive the climate change agenda is identified. The interdisciplinary position of geography is seen to offer many advantages to contribute to progress in the climate change arena.
\end{abstract}

Keywords: climate change; mitigation; adaptation; Ireland

For weather and climate, Ireland is a kind of sentry post for much of north-western Europe. As polar and tropical air masses battle it out in the Atlantic, Ireland provides the harbingers of weather further east, and much of Europe watches Ireland for a signal of what is coming down the line. It was precisely for this purpose that, as far back as 1860, Admiral Fitzroy recognised the strategic location of Valentia, with its telegraph link to London, when he was establishing an early network of weather observatories. Further north, it was the crucial observations from Blacksod Lighthouse on the Mullet peninsula of County Mayo in early June 1944 that delayed the D-Day landings in Normandy. A similar early warning service continues to be provided by Irish weather observations to the present day. However, in addition to being a sentry post, Ireland is also a shield that bears the brunt of Atlantic storms and their frontal rain, and functions as such to provide one of the principal controls on the climate of Britain to the east.

Yet, Ireland also has its own distinctive geographical climate fingerprint. This results from what is an unusual physical configuration for an island of its size, comprising of a mountainous perimeter of hard ancient rocks and a relatively soft, lowlying, interior. This combined with the fretted coastline of the west and south provides a surprisingly varied climatic mosaic to the island. Spatially, temperature variations are

*Email: john.sweeney@nuim.ie 
quite marked, though they reflect in their equability the overall dominance of maritime controls. For precipitation, while annual rainfall totals over 3 metres can be expected on the western mountains, these give way to values as low as $710 \mathrm{~mm}$ in the commuter towns west of Dublin. And while 50 days of gale force winds can be experienced in a typical year on the north west coast, this reduces to only two in the sheltered inland valleys of the south east.

Not surprisingly for such an exposed location on the perimeter of Europe, extremes of weather are deeply ingrained. Fear of storm and flood has always been a feature of a national obsession with weather. This is well justified. The 'Night of the Big Wind' in 1839, so meticulously documented in an earlier issue of Irish Geography (Shields and Fitzgerald 1989), the extra tropical remnants of Hurricane Charley in 1986 and the catastrophic floods of November 2009 have all left their mark on the folk memory. Perhaps only once was the fear of storm trumped by an even greater fear, as evidenced in the early ninth century Irish monk's prayer:

There's a wicked wind tonight,

Wild upheaval in the sea;

No fear now that the Viking hordes

Will terrify me.

The Vikings ventured out into the open Atlantic at a time of benign climate over much of northern Europe. Harvests were easier and the knowledge that food security was less of a pressing issue than hitherto has historically encouraged expansionary tendencies. We now know that this Medieval Warm Period was probably not global in extent, but, for places such as Ireland, represented probably the warmest episode since the post-glacial climatic optimum around 6,000 years ago. The slow descent into the Little Ice Age which followed produced food insecurity long before the Great Famine. In the famine which accompanied 'The Great Frost' of 1741, some estimates suggest that up to $38 \%$ of the population may have perished (Dickson 1997). Clearly, climate fluctuations are an inherent part of the Irish climate and a historic vulnerability exists.

Once again, Ireland stands on the threshold of climate change. As a mid-latitude country one can expect its future temperature changes to largely mirror global trends. Temperature at Irish weather stations has already increased by $0.7^{\circ} \mathrm{C}$ over the past century; frost days have decreased and significant changes in rainfall intensity and seasonality have been detected (McElwain and Sweeney 2007). Currently, an increase of $1.4-1.8^{\circ} \mathrm{C}$ by mid-century, as compared with the $1961-1990$ baseline period, is projected (Fealy and Sweeney 2008a). Changes in rainfall are, however, more difficult to be definitive about. But, whether we use a Regional Climate Model (McGrath and Lynch 2008), or a Statistical Downscaling approach (Fealy and Sweeney 2008b), winters are projected to become wetter by about $10 \%$ by mid-century, while summers become drier by a roughly similar amount. Though seemingly not a large departure from the present, especially in view of recent cold winters and wet summers, departures from such a new climate norm would bring a new raft of extremes and have enormous significance for flood management, water quality management, agriculture, forestry, tourism, biodiversity, energy demand and so on. In short, as the climate changes, Ireland changes in a range of ways for which advance planning is needed.

What can we learn from the past? How should we adapt to the future? How should we position Ireland to not be a loser as global climate changes occur? These 
are issues addressed in this Special Issue of Irish Geography. No all-encompassing solution exists to provide all the answers necessary, but a flavour of some of the considerations, tools and instruments which can illuminate the problem are provided. Climate change is increasingly recognised as embodying a set of problems that cannot be resolved with traditional analytical approaches. DeGrace and Stahl (1990) labelled such problems 'Wicked Problems'. What is quite clear is that a strongly interdisciplinary approach is essential if a coherent strategy to resolving this 'wicked problem' is to be developed. Interdisciplinarity has not been a feature of traditional research approaches. However it has always been central to geography. In this respect, the geographer is ideally positioned to make a significant contribution to the 'wicked problem' of climate change.

In common with countries such as Japan, China and Iceland, Ireland has a great tradition of documenting weather and climate extremes. Indeed, what is probably the earliest written account of a weather event in western Europe, allegedly in 2668BC, can be traced to an early Irish manuscript - The Annals of the Four Masters though corroboration of dates and events is impossible. In more recent times, individual weather events have played a crucial role at various times in Irish history (Tyrell 1997). At critical junctures following disruptive climate events, choices have been made and lessons learned. The ongoing gaze of humans on climate hazards is examined by James Mitchell in his paper in this issue, as he examines a variety of documentary sources ranging from monastic manuscripts, to letters, diaries and newspapers and their links to policy formulation. He urges those concerned with climate change adaptation to learn from the past and argues that the experience of past transitions should not be cast aside as we face an uncertain future.

Uncertainty will always underlie decision-making as regards coping with future climate change. Despite the complexity of modern modelling approaches, it must be recognised that natural and human-driven influences on climate may not always be working in the same direction, and our knowledge of key processes remains incomplete. Conor Murphy et al. demonstrate this here with reference to hydrological modelling, using the Boyne catchment as a case study. Other catchments in Ireland show similar sources of uncertainty (Bastola et al. 2011). As with many things, the more we know, the less we know, and Murphy et al.'s paper highlights the fact that uncertainty is not likely to be eliminated during the timescale required for critical decisions. But this cannot be an excuse for inaction. The precautionary principle and a 'no regrets' approach is a responsibility we have to future generations. A paradigm shift in how climate impact assessments can inform the adaptation agenda is called for.

The Irish landscape is a treasure chest of valuable natural habitats and ecosystems, distinctively oceanic in character by virtue of the island's location. These respond to changes in climate on a variety of timescales and as a result of complex interactions with other influencing factors such as soils, moisture availability, competition, dispersal capability etc. Some trees for example now leaf in Ireland 30 days earlier than 30 years ago (Donnelly et al. 2006), while some other species may become extinct or invasive. As regards the most distinctive habitats, perhaps the 'crown jewels' are our wetlands, especially our blanket bogs, turloughs and raised bogs, the latter among the last vestiges of such ecosystems in western Europe. These are threatened by summer drying in a changed climate. Cracking of the peat surface may result in a greater susceptibility to decomposition and erosion in wetter winter conditions. Conserving these unique environments is also proving difficult in what is often a hostile 
environment at the local political level. But they are also great repositories of carbon, which if lost will undo much of the national effort to curtail greenhouse gas emissions. It has been estimated that there are 1.2 billion tonnes of carbon in Irish peatland stores (Tomlinson 2005) and a rough estimate suggests they sequester between 60-140,000 tonnes of carbon annually (Wilson et al. 2007). Disturbance can radically reduce sequestration and even initiate emissions of greenhouse gases. Tools to monitor the health and integrity of such systems are thus essential, and John Connolly and Nick Holden's paper address this need with a satellite-based approach capable of being exported beyond Ireland.

Understanding where the pressures will arise, and what species will be under threat, is essential information to prioritise conservation efforts. We know that the geography of Arctic and Boreal relict species such as Arctic Char, Smelt and Pollan will be first in the firing line. Other species at their southern limit in Europe will also be stressed, as will many wetland species intolerant of summer dryness. In contrast species at the northern edge of their range will benefit, especially insects such as some butterflies (Byrne et al. 2003). Climate envelope modelling provides a tool to address this, as well as pointing to what new invasive species might find a home in a changed Irish climate. Powerful new statistical tools combined with a GIS-based approach have become central instruments in modern geographical research in such areas and John Coll et al. employ these techniques to examine the likely health of blanket bogs in a future Ireland. Using a Generalised Linear Model-based approach, the probability of changes on each $10 \mathrm{~km}$ grid square in Ireland is assessed. Such an approach can guide planning and conservation strategies not just for peatlands, but for a range of threatened land cover types and species.

The relevance of a physical geographical approach to environmental management is nowhere better demonstrated than in vulnerability to flood hazard. The absence of basic geographical considerations in land use planning, and the priority of maximising short-term economic gain, has produced in some cases greatly enhanced exposure of people and their structures to flooding. Wetter winters ahead will change the magnitude and frequency of major events and exacerbate vulnerability. Jim Jeffers examines this question of how flood risk management is positioned vis a vis climate change adaptation. Using the Cork City flood of November 2009 as a case study, he examines the limits of current policies and practices, especially insofar as they emphasise solutions based on engineering and technical fixes. As the challenge increases due to climate change, he concludes that the steps being taken will prove inadequate and that more radical changes in policy and practice will be essential.

Policies to tackle this defining challenge of the twenty-first century are failing at both a global and local level. The failure of the international community to conclude a binding and comprehensive agreement to limit greenhouse gas emissions has been well publicised in the post-Copenhagen period. The changing geography of these emissions makes the outlook for such an agreement bleak at present. As a consequence, the atmospheric concentration of $\mathrm{CO}_{2}$ is accelerating upward from decade to decade and will breach $400 \mathrm{ppm}$ within the next five years placing the planet on track for the most pessimistic outcomes from the current generation of global climate models.

Anticipating and adapting to climate change requires action at all levels. The global scale issues of equity and cost are equally valid at a local level. Here also progress is slow. Jackie McGloughlin and John Sweeney explore the hiatus between aspiration and 
reality at local government level, a facet not unique to Ireland. The investigation has revealed only a patchy distribution of best practice examples among Irish local authorities, with some displaying serious forward planning for adapting to climate change, and some others mainly rooted at the level of aspiration only. Limited vertical integration among the various levels of governance is identified as a stumbling block to policy implementation. If effective action is to be taken, leadership from central government to drive the climate change agenda is seen as urgently required in the context of formalised commitments and mandatory local implementation.

As a topic, climate change has moved from the periphery of climatology to the centre of geography in two decades. This is partly because geographers have the synthesis skills necessary to provide integrated spatial insights not available to more specialist disciplines in either the physical or social sciences. Strengthening the knowledge base, refining the model projections, encouraging political courage - these are the priority areas in which Irish geographers can and are working. As an outreach discipline, geography can also contribute considerably to reversing the damage done by sceptics and denialists in distorting the scientific communication flows to the public at large. This issue of Irish Geography offers only a glimpse of the contribution that Irish geographers are already making in key areas which will shape the future physical and socio-economic landscape of Ireland.

\section{References}

Bastola, S., Murphy, C., and Sweeney, J., 2011. The role of hydrological modelling uncertainties in climate change impact assessments of Irish river catchments. Advances in Water Resources, 34 (5), 562-576.

Byrne, C., Jones, M., and Donnelly, A., 2003. Assessment of the impacts of climate change on biodiversity in Ireland. In: J. Sweeney, ed. Climate change: Scenarios and impacts for Ireland. Johnstown Castle, Wexford: Environmental Protection Agency, 121-140.

DeGrace, P. and Stahl, L.H., 1990. Wicked problems, righteous solutions. Englewood Cliffs, NJ: Prentice Hall.

Dickson, D., 1997. Arctic Ireland: The extraordinary story of the Great Frost and Forgotten Famine of 1740-41. Belfast: White Row Press.

Donnelly, A., Salamin, N., and Jones, M.B., 2006. Changes in tree phenology: An indicator of spring warmth in Ireland? Proceedings of the Royal Irish Academy, 106 (1), 47-55.

Fealy, R. and Sweeney, J., 2008a. Climate scenarios for Ireland. In: J. Sweeney, ed. Climate change in Ireland: Refining the impacts. Johnstown Castle, Wexford: Environmental Protection Agency, 5-38.

Fealy, R. and Sweeney, J., 2008b. Statistical downscaling of temperature, radiation and potential evapotranspiration to produce a multiple GCM ensemble mean for a selection of sites in Ireland. Irish Geography, 41 (1), 1-27.

McElwain, L. and Sweeney, J., 2007. Key meteorological indicators of climate change in Ireland. Johnstown Castle, Wexford: Environmental Protection Agency.

McGrath, R. and Lynch, P., eds., 2008. Ireland in a warmer world. Scientific predictions of the Irish climate in the twenty-first century. Dublin: Community Climate Change Consortium for Ireland.

Shields, L. and Fitzgerald, D., 1989. The 'Night of the Big Wind' in Ireland, 6-7 January 1839. Irish Geography, 22 (1), 31-43.

Tomlinson, R., 2005. Soil carbon stocks and changes in the Republic of Ireland. Journal of Environmental Management, 76 (1), 77-93.

Tyrell, J., 1997. The weather and political destiny. In: J.A. Murphy, ed. The French are in the bay. Cork: Mercier Press.

Wilson, D., Tuittila, E.-S., Alm, J., Laine, J., Farrell, E.P., and Byrne, K.A., 2007. Carbon dioxide dynamics of a restored maritime peatland. Ecoscience, 14 (1), 71-80. 